\title{
Effects of Gradual Feed Dilution with Inert or Less Nutritive Materials on Growth Performance, Feed Cost and Meat Organoleptic Properties of Broiler Chicken
}

-Author(s)

\section{Atapattu NSBM'}

Silva LMS

Department of Animal Science, Faculty of Agriculture, University of Ruhuna, Mapalana, Kamburupitiya, Sri Lanka

\section{Mail Address}

Corresponding author e-mail address N.S.B.M. Atapattu

Department of Animal Science, Faculty of Agriculture, University of Ruhuna, Mapalana, Kamburupitiya, Sri Lanka Phone: ++94 412292200

Email: nsbm@ansci.ruh.ac.lk

\section{EKeywords}

Broiler, Dilution, Feed, Performance, Phase.

\section{ABSTRACT}

The objective of the present study was to determine the effects of the gradual dilution of broiler finisher diets with inert or less nutritive materials on growth performance, feed cost, and meat organoleptic properties. Broiler chicks $(n=147)$ were allocated into 49 pens and fed a mash broiler finisher diet (control) or the control diet diluted either with cassava leaf meal (CLM), gliricidia leaf meal (GLM), grass meal $(G M)$, rice bran (RB), sand (SND), or sawdust (SD). For a given diluent, six diets were prepared by mixing the control diet with the respective diluents (w/W) at 0\% (fed from 27-28d),2\% (fed from 29-30d), 4\% (fed from 31-32d), 6\% (fed from 33-34d), 8\% (fed from 35-36d) and $10 \%$ (fed from 37-40d). SD, RB, GLM and GM significantly reduced the diluent-adjusted feed intake (total feed intake-diluent intake). Except for GLM and SD, other diluents resulted in similar weight gains as the control diet. The dietary dilution with rice bran reported the best feed conversion ratio (FCR) (1.91). The total feed cost of the birds fed control and sand diluted diet was higher $(p<0.001)$ than those fed other diets. Compared with the control diet, the gradual dilution of feed with RB and SND reduced the feed cost per $\mathrm{kg}$ of live weight gain by 12 and 10 Rs, respectively. Meat organoleptic properties of the birds fed RB diluted diet were similar to those of the control birds. It was concluded that gradual feed dilution with inert or less nutritive materials could be used as an alternative to conventional phase feeding. Among the tested materials, rice bran was identified as the best candidate for such gradual feed dilution programs.

\section{INTRODUCTION}

Supplying diets that meets the actual nutritional requirements at lowest cost is critically important to optimize the production performance and welfare of poultry, while minimizing nutrient excretion. However, it is extremely difficult to establish nutrient requirements, as they are influenced by many factors, including age. The requirements of many nutrients, including amino acids (Pope \& Emmert, 2001; Emmert \& Baker, 1997), P and Ca (Angel et al., 2000; Dhanu et al., 2000), and vitamins (NRC 1994) reduce as broilers mature. Phase feeding, where a number of diets with decreasing nutrient densities are fed during identified age phases of growth, reduces feed cost and nutrient excretion (Pope \& Emmert, 2001). Feeding three, four (Dozier et al., 2006), six (Brewer et al., 2012) diets during the grow-out cycle or changing diets weekly (Pope \& Emmert, 2001), every three days (Gutierrez et al. 2008) and every other day (Pope et al., 2002), have been adopted. Although a high number of feeding phases improves nutrient utilization efficiency and minimizes nutrient excretion, too many feeds result in additional logistic, technical, financial, and transport costs both at feed mill and 
farm level (Dozier et al., 2006). Therefore, the typical phase feeding methods involving the formulation of different diets according to lysine requirements based on regression equations are not popular among feed millers and farmers. In this context, simple phase feeding strategies that can be adopted at farm level to gradually reduce feed nutrient density are of importance.

Dilution of dietary nutrient levels is a common practice in early feed restriction strategies (Moradi et al., 2013). Wood charcoal (Rezaei et al., (2006), rice husks (Rezaei \& Hajati, 2010; Incharoen, 2013), oat hulls (Qaisrani et al., 2013) and sand (Sellers et al., 1980; Farjo et al., 1986; Rowland et al., 1980) have been studied as diluents of poultry diets. However, in conventional feed restriction programs, diet dilution is followed by an ad libitum feeding period, during which birds exhibit a compensatory feeding behavior, resulting in total feed intake comparable with that of control birds. Some studies (Qaisrani et al., 2013; Leeson et al., 1992) found that at some dilution levels, broilers were not able to adjust their feed intake to maintain the same energy intake as that of the control birds. Qaisrani et al. (2013) reported that high levels of diet dilution with oat hulls resulted in long-term stress, as determined by a high heterophil/ lymphocyte ratio.

Under these circumstances, we hypothesized that the gradual dilution of broiler diets can be used as an alternative approach to the typical phase-feeding methods. In order to maximize the possible financial benefits, non-nutrients, such as sand, and relatively less nutritive and cheap feed ingredients, such as rice bran, were evaluated as feed diluents. Since mature broilers are more capable of tolerating low-quality diets and two thirds of the feed intake takes place during the finisher stage (Wickramasinghe et al., 2014), it is hypothesized that a gradual feed dilution would yield more benefits when adopted for finisher broilers. The present study evaluated the effects of a gradual feed dilution program with six diluents on the growth performance, feed cost, carcass parameters, and meat organoleptic properties of broiler chickens.

\section{MATERIALS AND METHODS}

The experiment was conducted at the Poultry Research Facility of the Faculty of Agriculture, University of Ruhuna, Kamburupitiya (6.060971 N, 80.563817 E), Sri Lanka. Day-old Cobb 500 male broiler chicks (CIC Feeds, Sri Lanka) were brooded under an electric brooder for 10 days. All birds were fed a commercial broiler starter diet (CIC Feed, Sri Lanka) until day 21 and a nutritionally-balanced broiler finisher diet (NRC, 1994) prepared on the farm until day 26 (Table 1). On day 26, 147 chicks were allocated to 49 floor pens ( 3 birds per pen), maintaining minimum body weight variation. Pens were distributed according to a completely randomized experimental design with seven dietary treatments of seven pens each. Diets were fed from day 27-40. The control treatment consisted of a nutritionally-balanced broiler finisher diet (Table 1). The other treatments consisted of the control diet diluted with one of the six diluents (CLM, GLM, GM, $\mathrm{RB}, \mathrm{SND}$, or SD). The nutritional composition of the diluents is shown in Table 2. For a given diluent, six diets were prepared by mixing the control diet and respective diluents (W/W) at 0\% (fed from $27-28 \mathrm{~d}$ ), $2 \%$ (fed from 29-30d), 4\% (fed from 31-32d), 6\% (fed from 33-34d), 8\% (fed from 35-36d) and 10\% (fed from 37-40d).

Cassava (Manihot esculenta) and gliricidia (Gliricidia sepium) leaves without stalks, and mature grass (Panicum maxicum) leaves were sun-dried and ground to get respective meals. Fresh RB was obtained from a local mill. Masonry sand was washed, dried, and sieved using 0.5-mm mesh. Albizea (Albizea lebbeck) sawdust was collected from a local mill and sun-dried.

Each pen was equipped with a bell-shaped drinker and feeder. Feed and water were offered ad libitum. Paddy husk was used as litter substrate. Feed intake was determined by subtracting the weight of left over feed from the weight of the feed offered. The diluentadjusted feed intake was defined as feed intake minus calculated diluent intake. Birds were weighed in the morning of $d 34$. All birds were deprived of feed for six hours on day 41 and then weighed.

One randomly selected bird per pen was sacrificed by cervical dislocation on day 41 and dissected to determine the carcass parameters. Liver, heart, gizzard, crop, pancreas, empty small intestine and, cloacal, abdominal and gizzard fat weights were determined and expressed as a percentage of empty carcass weight. The length of the small intestine, measured from gizzard-duodenum junction to ileo-ceco-colic junction, was expressed as a percentage of empty carcass weight.

Blood samples collected from one randomly selected bird per pen on d 38 were analyzed for serum cholesterol using a commercial assay kit (SPINREACT, S.A. Ctra, Santa Coloma, Spain). 
Breast meat samples were boiled for 30 minutes and assessed for their organoleptic properties by 40 semi-trained panelists. Panelists were asked to rank meat for appearance, color, odor, texture, taste, and overall acceptability on a five-point Likert scale; $2=$ like very much, $1=$ like, $0=$ no like nor dislike, -1 dislike, and -2 dislike very much.

Growth performance and carcass parameters were statistically analyzed according to a completely randomized design, using the GLM procedure of SPSS (IBM SPSS Statistics). Means were compared using Duncan's multiple range test at $p<0.05$. Organoleptic properties were compared using the non-parametric test of Kruskal-Wallis.

Table 1 - Ingredient composition and calculated nutrient composition of the control diet

\begin{tabular}{ll}
\hline Ingredient & $\mathrm{g} / \mathrm{kg}$ \\
\hline Corn meal & 500 \\
\hline Soybean meal & 290 \\
\hline Rice bran & 100 \\
\hline Coconut oil & 50 \\
\hline Fish meal & 30 \\
\hline Dicalcium phosphate & 13 \\
$\mathrm{CaCO}_{3}$ & 11 \\
\hline DL Methionine & 1 \\
\hline Salt & 2.5 \\
Vit/Trace Mineral mix & 2.5 \\
Nutrient composition (calculated) & \\
\hline Metabolizable energy (kcal/kg) & 3100 \\
\hline Crude protein (g/kg) & 200 \\
Ca (g/kg) & 9.5 \\
\hline Non-phytate phosphorus (g/kg) & 3.5 \\
\hline Lysine (g/kg) & 11 \\
\hline Methionine + Cysteine (g/kg) & 7.9 \\
\hline Crude fiber(g/kg) & 43 \\
\hline Cost (SL Rupees) & 92.00 \\
\hline
\end{tabular}

*Provided per kilogram of diet: vitamin A, 7,000 IU; vitamin D3, $700 \mathrm{IU}$; vitamin $\mathrm{E}$, $40 \mathrm{mg}$; vitamin $\mathrm{K} 3,4 \mathrm{mg}$; thiamine, $7 \mathrm{mg}$; riboflavin, $5 \mathrm{mg}$; pyridoxine, $5 \mathrm{mg}$; vitamin B12, $25 \mu$ g; pantothenate, $10 \mathrm{mg}$; nicotinic acid, $50 \mathrm{mg}$; folic acid, $1 \mathrm{mg}$; biotin, 70 $\mu \mathrm{g}$; Zn as zinc sulfate, $100 \mathrm{mg}$; Fe as ferrous sulfate, $80 \mathrm{mg}$; Cu as copper sulfate, 7 $\mathrm{mg}$; I as calcium iodate, $1.5 \mathrm{mg}$; $\mathrm{Se}$ as sodium selenite, $0.3 \mathrm{mg}$; and $\mathrm{Mn}$ as manganese sulfate, $5 \mathrm{mg}$

"As of Nov 2014

\section{RESULTS AND DISCUSSION}

\section{Growth performance: Phase 1}

On day 33, except for the control diet, all other diets had gradually been diluted up to $4 \%$ with the respective diluents. The feed intake of the birds fed diets diluted with all diluents, except for RB, were not significantly different from that of the control birds (Table 3). On day 33, birds fed diets diluted with RB showed a lower $(p<0.01)$ feed intake compared to those fed the diet diluted with CLM. Neither the CLM nor the RB diets, which resulted in the highest and lowest feed intake, respectively, had significant effects on body weight on day 33, weight gain from day 27-33, or FCR. These results suggest that the gradual dilution of broiler finisher diets up to $4 \%$ from days $27-33$ with the evaluated diluents does not depress the growth performance of broilers. This is in agreement with the findings of Leeson et al. (1996), who reported a significant reduction of broiler growth performance later (42-49d), but not the initial period (35-42d) of feeding a diluted diet. In the present experiment, negative effects of feed dilution particularly with GLM and GM, on growth performance, were also observed from 34-41 days.

\section{Growth performance: Phase 2}

During the second phase, diet dilution was over $4 \%$. The feed intake of the broilers fed the diets diluted with CLM, GM, RB, and SD was similar to that of control group. Birds fed the GLM presented lower feed intake $(p<0.01)$, live weight on day $41(p<0.01)$, and weight gain from day 34-41 $(p<0.01)$ compared with the control, and the highest FCR value among treatments. Diet dilution with SND increased broiler feed intake $(p<0.001)$, but had no effect on live weight on day 41, weight gain and FCR, compared with the control diet. Although not significantly different from the control, the best FCR value was recorded in the birds fed the RB-diluted diet, which in turn was lower $(p<0.01)$ than those fed the diets diluted with GLM, GM, and SD.

Table 2 - Nutrient composition of the diluents

\begin{tabular}{|c|c|c|c|c|c|c|c|c|c|}
\hline Diluent & $\mathrm{CP}(\%)^{1}$ & ME (kcal/kg) & CF $(\%)$ & Lysine (\%) & Methionine (\%) & Fat $(\%)^{2}$ & $\mathrm{Ca}(\%)$ & $\mathrm{P}(\%)$ & $\operatorname{NDF}(\%)$ \\
\hline CLM & 22 & $1800^{3}$ & 17.7 & $1.23^{3}$ & $0.40^{3}$ & 6.8 & 1.1 & 0.37 & 42.3 \\
\hline GLM & 21.2 & & 19.7 & & & 1.4 & 1.1 & 0.23 & 49.7 \\
\hline GM & 8.2 & & 37.3 & 0.62 & 0.22 & 1.8 & 0.49 & 0.24 & 72.3 \\
\hline $\mathrm{RB}$ & 11.2 & $2980^{4}$ & 11.4 & 0.69 & 0.32 & 16.4 & 0.07 & 1.7 & 25.2 \\
\hline SD & 1.4 & & & & & & & & \\
\hline
\end{tabular}

1,2 Calculated values

${ }^{3}$ Derived from Ravindran (1993)

${ }^{4}$ NRC (1994)

Other values are as given in Feedipidea (http://www.feedipedia.org) 
Table 3 - Growth performance and feed cost of broiler finishers fed control diet or diets gradually diluted with six materials.

\begin{tabular}{|c|c|c|c|c|c|c|c|c|c|}
\hline \multirow[t]{3}{*}{ Parameter } & \multicolumn{7}{|c|}{ Dilution material } & \multirow{3}{*}{$\begin{array}{l}\text { Pooled } \\
\text { SEM } \\
\text { SEM }\end{array}$} & \multirow{3}{*}{$\begin{array}{l}\text { ANOVA } \\
\mathrm{p} \text { value }\end{array}$} \\
\hline & \multirow[t]{2}{*}{ CLM } & GLM & GM & $\mathrm{RB}$ & SND & SD & Control (no dilution) & & \\
\hline & & \multicolumn{6}{|c|}{ Feeding phase 1: Dilution up to $4 \%$ (from 27-33d) } & & \\
\hline Live weight (g) $27 \mathrm{~d}$ & 1008 & 1012 & 918 & 1010 & 1015 & 1012 & 1010 & 34.0 & 0.10 \\
\hline Feed intake (g) (27-33d) & $746^{a}$ & $690^{\mathrm{ab}}$ & $711^{\mathrm{ab}}$ & $665^{b}$ & $720^{\mathrm{ab}}$ & $709^{a b}$ & $718^{\mathrm{ab}}$ & 13.2 & 0.005 \\
\hline Live weight (g) $33 \mathrm{~d}$ & 1385 & 1347 & 1372 & 1346 & 1382 & 1362 & 1398 & 13.0 & 0.34 \\
\hline Weight gain (g)27-33d & 376 & 335 & 454 & 336 & 366 & 349 & 388 & 37.0 & 0.39 \\
\hline FCR27-33d & 1.98 & 2.06 & 1.81 & 1.81 & 1.97 & 2.04 & 1.85 & 0.13 & 0.43 \\
\hline \multicolumn{10}{|c|}{ Feeding phase 2: Dilution from 6-10\% (from 34-41d) } \\
\hline Feed intake(g) 34-41 & $1168^{\mathrm{ab}}$ & $1061^{d}$ & $1098^{\mathrm{cd}}$ & $1105^{\mathrm{cd}}$ & $1232^{a}$ & $1164^{\mathrm{bc}}$ & $1146^{\mathrm{bc}}$ & 21.0 & 0.00 \\
\hline Live weight (g) $41 \mathrm{~d}$ & $1921^{\mathrm{ab}}$ & $1175^{c}$ & $1857^{\mathrm{bc}}$ & $1939^{a b}$ & $2002^{a}$ & $1860^{\mathrm{bc}}$ & $1972^{\mathrm{a}}$ & 30.36 & 0.00 \\
\hline Weight gain (g)34-41d & $535^{\mathrm{abc}}$ & $428^{d}$ & $484^{\mathrm{cd}}$ & $592^{\mathrm{ab}}$ & $620^{a}$ & $498^{\text {bcd }}$ & $573^{\mathrm{abc}}$ & 34.0 & 0.00 \\
\hline FCR 34-41 & $2.18^{\mathrm{abc}}$ & $2.48^{\mathrm{a}}$ & $2.30^{\mathrm{ab}}$ & $1.87^{c}$ & $1.99^{b c}$ & $2.35^{\mathrm{ab}}$ & $2.07^{a b c}$ & 0.13 & 0.00 \\
\hline \multicolumn{10}{|c|}{ Overall performance (from $27-41 d$ ) } \\
\hline Total feed intake (g) & $1915^{\mathrm{ab}}$ & $1752^{d}$ & $1819^{\mathrm{bcd}}$ & $1771^{\mathrm{cd}}$ & $1953^{a}$ & $1873^{\mathrm{abc}}$ & $1865^{\text {abc }}$ & 33.0 & 0.00 \\
\hline Diluent-adjusted Feed intake $(\mathrm{g})$ & $1799^{\mathrm{abc}}$ & $1646^{e}$ & $1701^{\text {cde }}$ & $1662^{\text {de }}$ & $1832^{\mathrm{ab}}$ & $1758^{\text {bcd }}$ & $1865^{a}$ & 32.7 & 0.00 \\
\hline Weight gain (g) 27-41d & $912^{\mathrm{ab}}$ & $764.0^{\mathrm{b}}$ & $938.8^{\mathrm{ab}}$ & $929.7^{\mathrm{ab}}$ & $986.5^{a}$ & $847.8^{\mathrm{bc}}$ & $962.0^{\mathrm{a}}$ & 42.82 & 0.01 \\
\hline FCR & $2.10^{\mathrm{ab}}$ & $2.29^{a}$ & $2.00^{\mathrm{ab}}$ & $1.91^{b}$ & $1.98^{\mathrm{ab}}$ & $2.22^{\mathrm{ab}}$ & $1.96^{\mathrm{b}}$ & 0.10 & 0.00 \\
\hline Diluent-adjusted FCR & $1.97^{\mathrm{ab}}$ & $2.15^{\mathrm{a}}$ & $1.88^{\mathrm{ab}}$ & $1.79^{b}$ & $1.86^{\mathrm{ab}}$ & $2.08^{\mathrm{ab}}$ & $1.96^{\mathrm{ab}}$ & 0.01 & 0.00 \\
\hline Water:feed ratio & 2.71 & 2.57 & 2.86 & 2.86 & 2.86 & 2.86 & 3.00 & 0.150 & 0.55 \\
\hline Total feed cost ${ }^{1}$ & $168.00^{\mathrm{bc}}$ & $153.00^{d}$ & $158.86^{\mathrm{cd}}$ & $156.86^{\mathrm{cd}}$ & $169.57^{a}$ & $163.00^{\mathrm{cd}}$ & $172.71^{\mathrm{a}}$ & 2.1 .2 & 0.00 \\
\hline Total feed cost/kg gain² & $184.57^{\mathrm{abc}}$ & $201.86^{a}$ & $176.29^{b c}$ & $169.57^{c}$ & $172.57^{\mathrm{bc}}$ & $193.29^{\mathrm{ab}}$ & $182.43^{\mathrm{abc}}$ & 6.65 & 0.01 \\
\hline
\end{tabular}

Means followed by the same superscripts within a row are not significantly different at $p<0.05$

'Diluent adjusted feed intake=total feed intake-calculated diluent intake.

${ }^{2}$ Considering diluent costs: Cassava leaf meal $(C L M)=12.00$ Rupees; Gliricidia leaf meal $(G L M)=12.00$ Rs, Grass meal $(G M)=12.00$ Rs and Rice bran $($ RB $)=26.00$ Rs, Sand (SND) and Sawdust (SD) = No cost; Control diet $=92$ Rs. Control diet cost=92.00 Rupees.

\section{Overall performance $27-41 d$}

No mortality was reported during the experiment. Water to feed ratio was not affected by dietary treatments. Except for the GLM-fed broilers, total feed intakes were similar among the other diets. The GLM diet resulted in the lowest total feed intake, which was lower $(p<0.01)$ than that obtained with the control and SND-, SD- and CLM-diluted diets. Contrary to many earlier studies (Yang et al., 2015; Leeson et al., 1996; Onwudike 1983), no increase in feed intake due to feed dilution was observed in the present study. In fact, $\mathrm{SD}, \mathrm{RB}, \mathrm{GLM}$ and GM statistically reduced $(p<0.01)$ the diluent-adjusted feed intake, while SND and CLM resulted in numerical reduction (Table 3 ).

The main objective of the gradual feed dilution was to reduce nutrient intake by the birds as they mature. If feed intake had increased due to dilution, that objective would not have been achieved. Therefore, it is suggested that gradual feed dilution with inert or less nutritive materials could be used as an alternative to conventional phase feeding. A number of reasons alone or in combination may have determined the feed intake pattern when diets are diluted with different materials. On a one hand, diluents such as RB might not have induced a sufficient magnitude of energy reduction since it contributed some energy to overall dietary energy content. On the other hand, the significantly lower total feed intake and diluentadjusted feed intake of the birds fed the GLM-diet may have been due the presence of anti-nutrients, such as tannins, alkaloids and nitrates, in GLM (Ranaweera et al., 1981); Osei et al., 1990) and its repulsive smell (Lowry, 1990). Furthermore, bulk density differences among the diets and the degree of dilution may also have influenced feed intake and therefore need to be considered when a material is selected for a gradual feed dilution strategy.

GLM and SD dilution of the diet resulted in lower weight gain $(p<0.05)$ compared with the control diet, whereas the diets with the other evaluated diluents reported similar weight gains as the control diet. The highest FCR (2.29) obtained in the birds fed GLM diet was higher $(p<0.01)$ than those fed RB diluted diet and the control diet. Rice bran dilution resulted in the best FCR (1.91). The similar feed intake and growth performance of the broilers fed the RB, SND and CLM diet with the control group are contradictory to the results of Leeson et al. (1992), who reported lower feed intake and growth performance due to feed dilution. However, it those authors have applied a relatively more severe (10-50\%) dilution from day 35-49. 
Other feed restriction programs (Idahor 2013; Atapattu \& Chandrasiri 2009; Atapattu \& Lal, 2009) and diet dilution strategies (Yang et al., 2015; Leeson et al., 1996; Zubair \& Leeson 1994; Onwudike 1983) reported in literature resulted in increased feed intakes and thus failed to save feed costs. The analysis of the feed costs per $\mathrm{kg}$ of live weight gain showed financial advantages of gradual feed restriction strategy and, therefore, were used to determine the best candidate for such a feeding strategy. The total feed cost of the birds fed control and sand-diluted diet were significantly higher than those fed other diets. However, the feed costs per kg of live weight gain of the birds fed diets diluted with any of the materials were not significantly different from that of control birds. Although the total feed cost was lowest when the diet was diluted with gliricidia, this diet resulted in the highest feed cost per $\mathrm{kg}$ of live weight gain. Importantly, compared with the control diet, the gradual dilution of feed with RB and SND up to $10 \%$ reduced the feed cost by 12 and 10 Rs per $\mathrm{kg}$ of live weight gain, respectively.

Diluents accounted for $6 \%$ of the total feed intake across all treatments. The diluent-adjusted feed intake reduction ranged from $1.7 \%$ for SND to $11.7 \%$ for GLM (Table 4). The percentage reductions in FCR of the birds fed CLM, GLM and SD, compared with control group, were much higher than the respective reductions in adjusted feed intake. This suggests that the utilization efficiency of the nutrients was negatively affected when CLM, GLM and SD are used. In fact, CLM and GLM and SD are reported to contain antinutritional factors, such as tannins and alkaloids that can negatively affect digestion, absorption, and nutrient utilization efficiency (Ravindran, 1993; Ranaweera et al., 1981; Osei et al., 1990). In addition, when those materials were used, feed cost per $\mathrm{kg}$ of live weight gain was also higher than that of the control diet. Furthermore, diluents such as CLM, GLM, GM and SD resulted in lower dietary energy level (Table 4). Therefore, possibilities of using CLM, GLM, GM, and SD in a gradual feed dilution strategy are limited.
A number of studies have reported that inclusion of $5-10 \%$ sand in broiler diets had positive effects on energy utilization (Nam et al., 1998) and growth performance (Farjo et al., 1986; Rowland et al., 1980), or no adverse effects (Sellers et al., 1980). In line with those studies, the performance obtained with SND dilution in the present study was comparable to that of the control group (Table 3). However, due to the reasons given below, compared with SND, RB is identified as a better candidate than SND for this type of gradual feed dilution strategy. 1) It is noteworthy that the RB diet reduced feed intake by $10 \%$, while improving FCR by $2.2 \%$, compared with the control group. In contrast, SND caused only a marginal reduction in feed intake and improvement in FCR, compared with the control. This observation suggests that broilers fed the RB-diluted diet absorbed and/or utilized the limited amount of nutrients, particularly amino acids and minerals, more efficiently. Similar observations were reported in pigs and rats (Pond et al., 1982), as well as in broilers (Svihus \& Hetland 2001; Teeter \& Smith 1985; Leeson et al. 1992; Hernández et al., 2013). 2) RB resulted in the lowest feed cost per $\mathrm{kg}$ of weight gain. 3) Though the present experiment assumed that SND had no cost, this may not always be the case.4) Although the overall diet acceptability was not affected, some organoleptic properties, such as appearance, color and texture of the meat of SNDfed broilers was worse than those fed RB (Table 5).

The calculated energy and crude protein levels of the evaluated diets during the period of 27-41 days are given in Table 4. Sand dilution reduced the energy level of the diet up to $3000 \mathrm{kcal} / \mathrm{kg}$, whereas RB resulted in only a marginal reduction $(3092 \mathrm{kcal} / \mathrm{kg})$. Similarly, the CP level of RB and SND diluted diets were 19.4 and $18.7 \%$, respectively. Consequently, RB as a diluent may have had a lesser effect on energy level of the diet and better met the broilers' requirements of $\mathrm{CP}$ and probably other nutrients.

Contrary to the many studies in which dietary RB levels as low as 7.5\% and 10\% (Tangendjaja, 1993)

Table 4 - Diluent intake, diluent-adjusted feed intake, metabolizable energy and crude protein levels, and \% of change in feed intake and FCR of the broilers fed the diluted diets compared with the control diet

\begin{tabular}{|c|c|c|c|c|c|c|c|}
\hline \multirow[t]{2}{*}{ Parameter } & \multicolumn{6}{|c|}{ Diluent } & \multirow[t]{2}{*}{ Control } \\
\hline & CLM & GLM & GM & $\mathrm{RB}$ & SND & SD & \\
\hline Diluent intake (g) & 116 & 105 & 109 & 109 & 120 & 115 & 0 \\
\hline Diluent-adjusted feed intake (g) & 1799 & 1646 & 1701 & 1662 & 1832 & 1758 & 1865 \\
\hline Dietary ME level (kcal/kg)(27-41d) & 3015 & & & 3092 & 3009 & & 3100 \\
\hline Dietary CP level (\%) (27-41d) & 20.0 & 20.0 & 19.2 & 19.4 & 18.7 & 18.8 & 20 \\
\hline$\%$ change in feed intake relative to the control & -3.5 & -11.7 & -8.7 & -10.8 & -1.7 & -5.7 & \\
\hline$\%$ change in FCR relative to thecontrol & -7.1 & -16.8 & -2.0 & +2.2 & -1.0 & -13 & \\
\hline
\end{tabular}


reduced the feed intake and performance of broilers, the gradual feed dilution strategy adopted in the present experiment was able to use up to $20 \%$ RB without any adverse effects on performance. Therefore, the gradual feed dilution technique could be used to increase the RB inclusion level in broiler diets.

\section{Carcass parameters and meat organoleptic properties}

Despite the lowest feed intake, the length of the small intestine as a percentage of empty carcass weight of the broilers fed the GLM-diluted diet was higher $(p<0.05)$ compared to that of the control birds, indicating that their small intestine continued to grow despite the retardation of body growth rate (Table 6). Fassbinder-Orth \& Karasov (2006) also reported that the direction of nutrients for the growth of source organs such as small intestine gets priority over sink organs such as lean and fat. None of the other visceral organ weights and fat percentage were significantly affected by the diets. In contrast, Leeson et al. (1992) reported a significant reduction in abdominal fat due to feed dilution.

Meat appearance, color and texture scores of the broilers fed the diets diluted with sand and sawdust were significantly lower than those traits of control birds (Table 5). Organoleptic properties, such as appearance, color, texture, odor, taste and overall acceptability scores of the meat of broilers fed the RBdiluted diet were not different $(p>0.05)$ from those obtained for the meat of the control birds.
Unlike some conventional early feed restriction programs (Jones \& Farrell, 1992; Nielsen et al., 2003), no carcass fat reduction was recorded in this experiment. This may probably be due to the unaltered feed intake.

Contrary to the findings of Rezaei et al. (2010), serum cholesterol levels were not significantly affected by feed dilution.

Table $\mathbf{5}$ - Organoleptic properties of meat of broilers fed control or diets diluted with six materials

\begin{tabular}{|c|c|c|c|c|c|c|c|c|}
\hline \multirow{2}{*}{$\begin{array}{l}\text { Sensory } \\
\text { parameter }\end{array}$} & \multicolumn{7}{|c|}{ Feed diluents } & \multirow{2}{*}{$\begin{array}{c}\text { Kruskal } \\
\text { Wallis } \\
\text { p value }\end{array}$} \\
\hline & CLM & GLM & GM & RB & SND & SD & Control & \\
\hline Appearance & 1 & 1 & 1 & 1 & 0 & 0 & 1 & 0.00 \\
\hline Color & 1 & 1 & 1 & 1 & 0 & 0 & 1 & 0.00 \\
\hline Odor & 0.5 & 1 & 1 & 1 & 1 & 1 & 1 & 0.07 \\
\hline Texture & 1 & 1 & 1 & 1 & 0 & 0 & 1 & 0.04 \\
\hline Taste & 1 & 1 & 1 & 1 & 1 & 0 & 1 & 0.22 \\
\hline $\begin{array}{l}\text { Overall } \\
\text { acceptability }\end{array}$ & 1 & 1 & 1 & 1 & 1 & & 1 & 0.14 \\
\hline
\end{tabular}

\section{CONCLUSIONS}

It was concluded that feeding broilers with diets gradually diluted with rice bran or sand gives comparable growth performance as those fed a control diet and reduces feed cost. Gradual feed dilution may be applied as an alternative to conventional phasefeeding strategies. Among the tested materials, rice bran is recommended as the best candidate for such gradual feed dilution program.

Table 6 - Percentage visceral organ weights of the broilers fed control or diets gradually diluted with six materials

\begin{tabular}{|c|c|c|c|c|c|c|c|c|c|}
\hline \multirow[t]{2}{*}{ Parameter } & \multicolumn{7}{|c|}{ Feed diluents } & \multirow{2}{*}{$\begin{array}{c}\text { Pooled } \\
\text { SEM }\end{array}$} & \multirow{2}{*}{$\begin{array}{l}\text { ANOVA } \\
P \text { value }\end{array}$} \\
\hline & CLM & GLM & GM & $\mathrm{RB}$ & SND & SD & Control (no dilution) & & \\
\hline Empty carcass (g) & 1459 & 1244 & 1388 & 1377 & 1346 & 1294 & 1459 & 57 & 0.12 \\
\hline 'Liver \% & 3.0 & 3.2 & 3.2 & 3.2 & 3.0 & 3.3 & 3.4 & 0.2 & 0.85 \\
\hline${ }^{1}$ Heart \% & 0.67 & 0.70 & 0.72 & 0.767 & 0.661 & 0.688 & 0.680 & 0.51 & 0.82 \\
\hline${ }^{1}$ Gizzard \% & 2.51 & 2.57 & 2.68 & 2.49 & 2.57 & 2.52 & 2.33 & .127 & 0.63 \\
\hline${ }^{1}$ Crop \% & 0.58 & 0.53 & 0.51 & 0.59 & 0.65 & 0.58 & 0.42 & 0.05 & 0.09 \\
\hline Pancreas \% & .30 & .29 & .29 & .23 & .30 & .29 & .28 & .30 & 0.73 \\
\hline 'Small intestine weight & 3.64 & 3.73 & 3.78 & 3.83 & 3.27 & 3.74 & 3.71 & 0.25 & 0.82 \\
\hline${ }^{1}$ Clocal fat $\%$ & 2.61 & 2.68 & 2.28 & 2.93 & 2.65 & 2.80 & 2.39 & 0.27 & 0.68 \\
\hline${ }^{1}$ Gizzard fat \% & 0.50 & 0.45 & 0.48 & 0.37 & 0.43 & 0.53 & 0.46 & 0.07 & 0.84 \\
\hline${ }^{1}$ Proventicle & 0.56 & 0.56 & 0.62 & 0.62 & 0.52 & 0.59 & 0.51 & 0.06 & 0.81 \\
\hline${ }^{2}$ Small intestine length & $12.3^{b}$ & $14.2^{\mathrm{a}}$ & $11.8^{\mathrm{b}}$ & $12.8^{\mathrm{ab}}$ & $12.8^{\mathrm{ab}}$ & $13.2^{\mathrm{ab}}$ & $12.1^{\mathrm{b}}$ & 0.5 & 0.03 \\
\hline Serum cholesterol (mmol/dl) & 123 & 123 & 117 & 114 & 125 & 112 & 119 & 3.9 & 0.15 \\
\hline
\end{tabular}

Superscripts bearing same figures are not significantly different at $p<0.05$

'Weight as a \% of empty carcass

${ }^{2}$ Length $(\mathrm{cm})$ as a \% of empty carcass weight 


\section{Chicken}

\section{REFERENCES}

Angel R, Applegate TJ, Christman M. Effects of dietary non-phytate phosphorus (nPP) on performance and bone measurements in broilers fed on a four-phase feeding system. Poultry Science 2000;79(Suppl. 1):21-22.

Atapattu NSBM, Lal PK. Effects of feed withdrawal on growth performance and carcass parameters of broiler chicken. Sri Lanka Journal of Animal Production 2009;5(1):1-14

Atapattu NSBM, Chandrasiri WCJ. Effects of a qualitative feed restriction strategy on the growth performance and feed cost of mature broiler chicken. Matara: University of Ruhuna; 2009. p.113-118

Brewer VB, Owens CM, Emmert JL. Phase feeding in a big-bird production scenario: Effect on growth performance, yield, and fillet dimension. Poultry Science 2012;91(5):1256-1261.

Dhandu AS, Angel R, Applegate TJ, Ling B. Non-PP requirement of broilers in the finisher phase of a four phase feeding program. Poultry Science 2000;79(Suppl. 1):10.

Dozier WA, Gordon RW, Anderson J, Kidd MT, Corzo A, Branton SL. Growth, meat yield, and economic responses of broilers provided three-and four-phase schedules formulated to moderate and high nutrient density during a fifty-six-day production period. Journal of Applied Poultry Research 2006;15(2):312-325.

Emmert JL, Baker DG. Use of the ideal protein concept for precision formulation of amino acid levels in broiler diets. Journal of Applied Poultry Research 1997;6:462-470.

Farjo GY, Al-Saigh AS, Ibrahim IK. Effects of dietary dilution with sand on broiler performance to 8 weeks of age. British Poultry Science $1986 ; 27(3): 385-390$

Fassbinder-Orth, CA, Karasov, WH. Effects of feed restriction and realimentation on digestive and immune function in the leghorn chick. Poultry Science 2006;85(8):1449-1456.

Hernández F, Megia MD, Orengo J, Martinez S, Lope MJ, Madrid J. Effect of dietary protein level on retention of nutrients, growth performance, litter composition and $\mathrm{NH3}$ emission using a multiphase feeding programme in broilers. Spanish Journal of Agricultural Research 2013;11(3):736-746.

Idahor KO, Yakubu A, Egahi JO, Gwaza DS, Ahmadu GB, Thani AP. Growth Performance, carcass characteristics and cost benefits of four broiler strains on restricted feeding regimen in North Central Nigeria. Journal of Animal Science Advances 2013;3(9):449-456

Incharoen T. Histological adaptations of the gastrointestinal tract of broilers fed diets containing insoluble fiber from rice hull meal. American Journal of Animal and Veterinary Science 2013;8(2):79-83.

Jones GP, Farrell DJ. Early-life food restriction of broiler chickens. I. Methods of application, amino acid supplementation and the age at which restrictions should commence. British Poultry Science 1992;33:579_ 587.

Leeson S, Summers JD, Caston LJ. Response of broilers to feed restriction or diet dilution in the finisher period. Poultry Science 1992;71(12):20562064

Leeson S, Caston L, Summers JD. Broiler response to energy or energy and protein dilution in the finisher diet. Poultry Science 1996;75(4):522528.

Lowry JB. Toxic factors and problems: methods of alleviating them in animals. Shrubs and tree fodders for farm animals. Proceedings of a Workshop in Denpasar; 1990. Jacanta. Indonesia: IDRC; 1990 p.76-88.

Moradi S, Zaghari M, Shivazad M, Osfoori R, Mardi M. Response of female broiler breeders to qualitative feed restriction with inclusion of soluble and insoluble fiber sources. Journal of Applied Poultry Research 2013;22(3):370-381
Nam KT, LeeHA, Joo YJ, Kim KH, Kang CW. Influence of builder's sand on the TME of linseed for poultry. Animal Feed Science and Technology 1998:72(1): 199-201.

Nielsen BL, Litherland M, Nøddegaard F. Effect of qualitative and quantitative feed restriction on the activity of broiler chickens. Applied Animal Behavioural Science 2003;83:309-323

NRC. Nutrient requirements of poultry. 9th ed. Washington: National Academy Press; 1994

Onwudike OC. Energy and protein requirements of broiler chicks in humid tropics. Tropical Animal Production 1983;8:39-44.

Osei SA, Opoku RS, Atuahene CC. Gliricidia leaf meal as an ingredient in layer diets. Animal Feed Science and Technology 1990;29(3):303-308.

Pond WG, Mersmann HJ, Yen JT. Severe feed restriction of pregnant swine and rats: effects on postweaning growth and body composition of progeny. Journal ofnutrition 1985;115(2):179-189

Pope T, Emmert JL. Phase-feeding supports maximum growth performance of broiler chicks from forty-three to seventy-one days of age. Poultry Science 2001;80(3):345-352

Qaisrani SN, Van Krimpen MN, Kwakkel RP. Effects of dietary dilution source and dilution level on feather damage, performance, behavior, and litter condition in pullets. Poultry Science 2013;92:591-602

Ranaweera KNP, Siriwardene JA, Manamperi HBS. The feeding value of gliricidia leaf meal for broiler chickens. Ceylon Veterinary Journal 1981;29: 4-6

Ravindran V. Cassava leaves as animal feed: potential and limitations Journal of Science Food and Agriculture 1993;61(2): 141-150.

RezaeiM, Teimouri A, Pourreza J, Sayyahzadeh H, Waldroup PW. Effect of diet dilution in the starter period on performance and carcass characteristics of broiler chicks. Journal of Central European Agriculture 2006;7(1):63-70.

Rezaei M, Hajati H. Effect of diet dilution at early age on performance, carcass characteristics and blood parameters of broiler chicks. Italian Journal of Animal Science 2010;9(1): 19

Rowland LO, Hooze DM, Hooze JR. Effect of dietary sand on the performance of young broiler chicks. Poultry Science 1980;59:1907-1911.

Sellers RS, Harris GC, Waldroup PW. The effects of various dietary clays and fillers on the performance of broilers and laying hens. Poultry Science 1980;59(8):1901-1906.

SvihusB, Hetland $\mathrm{H}$. Ileal starch digestibility in growing broiler chickens fed on a wheat-based diet is improved by mash feeding, dilution with cellulose or whole wheat inclusion. British Poultry Science 2001;42(5):633-637.

Tangendjaja B. Effect of Fermacto upon the utilization of broiler diets containing normal and high levels of rice bran. Ilmu dan Peternakan 1993;16-19.

Teeter RG, Smith MO. Feed intake effects upon gain, carcass yield, and ration digestibility in broilers force fed five feed intakes. Poultry Science 1985:64(11):2155-2160

Wickramasinghe KP, Atapattu NSBM, Seresinhe, RT. Effects of citric acid on growth performance and nutrient retention of broiler chicken fed diets having two levels of non-phytate phosphorus and rice Bran. Iranian Journal of Applied Animal Science 2014;4(4):809-815.

Yang HZ, Yang Z, Wang W, Wang K, Huang W, Fan N, et al. Effects of early dietary energy and protein dilution on growth performance, nutrient utilization and internal organs of broilers. Italian Journal of Animal Science 2015;14(2):163-171

Zubair AK, Leeson S. Effect of varying period of early nutrient restriction on growth compensation and carcass characteristics of male broilers. Poultry Science 1994;73(1):129-136. 
